\title{
Effects of dietary Bacillus NP5 and sweet potato extract on growth and digestive enzyme activity of dumbo catfish Clarias sp.
}

\section{Efek Bacillus NP5 dan ekstrak ubi jalar pada pakan terhadap pertumbuhan dan aktivitas enzim pencernaan ikan lele dumbo Clarias sp.}

\author{
Achmad Noerkhaerin Putra ${ }^{1,2^{*}}$, Yayu Romdhonah ${ }^{3}$ \\ 'Department of Fisheries, Faculty of Agriculture, University of Sultan Ageng Tirtayasa \\ ${ }^{2}$ Indonesia-Center of Excellence for Food Security \\ ${ }^{3}$ Department of Agroecotechnology, University of Sultan Ageng Tirtayasa \\ Serang 42124, Banten, Indonesia \\ *Corresponding author: putra.achmadnp@untirta.ac.id
}

(Received March 29, 2018; Accepted November 13, 2018)

\begin{abstract}
This study aimed to investigate the effects of probiotic (Bacillus NP5), prebiotic (extracted from Ipomoea batatas var. sukuh,), and synbiotic on growth and digestive enzyme activity of dumbo catfish (Clarias sp.). Four treatments with 3 replications were used in the experiment, i.e; control, probiotic (1\% Bacillus NP5 in feed), prebiotic ( $2 \%$ sweet potato extract in feed), and synbiotic (1\% probiotic and $2 \%$ prebiotic in feed). After 45 days of rearing, catfish that were given probiotic, prebiotic, and synbiotic showed significantly $(\mathrm{P}<0.05)$ higher growth than that of the control. The average results on digestive enzyme activities in probiotic, prebiotic, and synbiotic treatments were significantly different $(\mathrm{P}<0.05)$ from that of the control. The addition of synbiotic to diets showed the best result on final weight, specific growth rate, feed conversion ratio, protein retention, protein efficiency ratio, and protease activities among other treatments.
\end{abstract}

Keywords: catfish, growth, probiotic, prebiotic, symbiotic

\begin{abstract}
ABSTRAK
Penelitian ini bertujuan untuk menginvestigasi pengaruh dari probiotik (Bacillus NP5), prebiotik (ekstrak ubi jalar varietas sukuh), dan sinbiotik terhadap pertumbuhan dan aktivitas enzim perncernaan ikan lele dumbo (Clarias sp.). Penelitian terdiri dari 4 perlakuan dan 3 kali ulangan, yakni: probiotik (Bacillus NP5 sebanyak 1\% dalam pakan), prebiotik (ekstrak ubi jalar sebanyak 2\% dalam pakan), dan sinbiotik (Bacillus NP5 1\% + ekstrak ubi jalar sebanyak $2 \%$ dalam pakan). Setelah pemeliharaan selama 45 hari, ikan lele pada perlakuan dengan suplementasi probiotik, prebiotik, dan sinbiotik dalam pakan secara signifikan $(\mathrm{P}<0,05)$ menghasilkan pertumbuhan yang lebih baik dibandingkan dengan kontrol. Nilai aktivitas enzim pencernaan pada perlakuan probiotik, prebiotik, dan sinbiotik secara signifikan berbeda $(\mathrm{P}<0,05)$ dari kontrol. Penambahan sinbiotik pada pakan memberikan hasil terbaik pada parameter bobot akhir, laju pertumbuhan harian, FCR, retensi protein, rasio efisiensi protein, dan aktivitas enzim protease dibandingkan dengan perlakuan lainnya.
\end{abstract}

Kata kunci: ikan lele, pertumbuhan, probiotik, prebiotik, sinbiotik. 


\section{INTRODUCTION}

Catfish stand the world's most important group of aquaculture species in terms of production. In Indonesia, Clarias sp. is one of popular catfish with 873.716 tons production rate in 2016 with intensive cultivation system is being used (DJPB, 2016). However, problems arise in the intensive cultivation system since this system requires high stocking density and amounts of feed (Widanarni et al., 2012). This certainly brings a negative impact on fish growth due to the high concentrations of organic compounds, which are dominated by nitrogenous wastes (Ekasari et al., 2010).

Supplementation of probiotic, prebiotic, and synbiotic in catfish diet is expected to increase growth performance of fish. Probiotic is an additional microbe which potentially provides beneficial effects for the host (Nayak, 2010). Probiotics can increase aquatic animal feed efficiency by stimulating digestive enzymes and maintaining the balance of intestinal microbes (Dawood \& Koshio, 2016). The influences of probiotic for fish and shrimp have been reported in various studies (Geng et al., 2012; Arig et al., 2013; Giri et al., 2013; Wang et al., 2014; Hauville et al., 2015, Imanpoor \& Roohi, 2015; Dawood et al., 2015; Ibrar et al., 2017; Dawood et al., 2017). Bacillus NP5 is probiotic bacteria which has beneficial effects in aquaculture. The application of Bacillus NP5 in fish diets improved growth performance and increase diseases resistance in tilapia Oreochromis niloticus (Utami et al., 2015; Putra \& Widanarni, 2015; Agung et al., 2015), white shrimp Litopenaeus vannamei (Widanarni et al., 2014), and Pangasianodon hypophthalmus (Tamamdusturi et al., 2016).

Prebiotic is a non-digestible food ingredient that beneficially affects the host by selectively stimulating the growth and/or the activity of one or a limited number of bacteria in the colon (Ringgø et al., 2010). Some studies have shown the benefits of using prebiotic for increasing growth performance (Buentello et al., 2010; Ringø et al., 2014; Selim \& Reda, 2015) and resistance of pathogen in aquaculture (Geraylou $e t$ al., 2013; Wang et al., 2014; Anuta et al., 2014). Prebiotic mainly consist of oligosaccharides (Merrifield et al., 2010) and could be found in various tuber plants, such as sweet potatoes Ipomoea batatas L (Moongngram et al., 2011). The utilization of sweet potatoes as prebiotic in tilapia fed improved growth performance and feed digestibility of tilapia (Putra, 2014; Putra et al. 2015). Marlida et al. (2014) reported that dietary sweet potato extract as a prebiotic can increase growth, digestive enzyme activity and health status of humpback grouper Cromileptes altivelis. Sweet potato is potential as a prebiotic source due to its oligosaccharide which is functional and indigestible by digestive enzymes (Marlida et al., 2014; Putra et al., 2015).

A synbiotic is defined as a combination of a probiotic and a prebiotic (Song et al., 2014; Akhter et al., 2015). It refers to nutritional supplements combining probiotics and prebiotics in the form of synergism (Kumar et al., 2017). Applications of synbiotic in the diet have been reported on growth performance, digestive enzyme activities and health status of several fish and shellfish species (Cerezuela et al., 2011; Lin et al., 2012; Zhang et al., 2013; De et al., 2014; Ring $\varnothing$ et al., 2014; Putra et al., 2015; Widanarni et al., 2016). However, limited data are available regarding the application of synbiotics in catfish. This study aimed to investigate the effects of probiotic (Bacillus NP5), prebiotic (extracted from Ipomoea batatas var. sukuh), and synbiotic in improving growth and digestive enzyme activity of dumbo catfish (Clarias sp.).

\section{MATERIALS AND METHODS}

\section{Preparation of probiotic, prebiotic, and synbiotic}

Probiotic bacteria used in the present study was Bacillus NP5 isolated from the digestive tracts of tilapia (Putra \& Widanarni, 2015). Isolates of Bacillus NP5 were cultured in trypticase soy broth medium for 18 hours at a temperature of $29^{\circ} \mathrm{C}$. The fresh culture was then harvested by centrifugation at speed of $1000 \mathrm{rpm}$ for $10 \mathrm{~min}$ to obtain the probiotic biomass. Probiotic were homogenized into phosphate buffered saline (PBS) for the addition to the feed. This study used a probiotic dose of $1 \%(\mathrm{~g} / 100 \mathrm{~g})$, referring to Putra et al. (2015).

The experimental prebiotic was extracted from sweet potatoes var. sukuh (Ipomoea batatas). The extraction process of the prebiotic was conducted in several stages referred to the method by Muchtadi (1989). A $10 \mathrm{~g}$ of steamed sweet potato meal was suspended in $100 \mathrm{ml}$ of $70 \%$ ethanol and stirred for $15 \mathrm{~h}$ using magnetic stirred at room temperature. The filtrate obtained was concentrated using a vacuum evaporator at $40^{\circ} \mathrm{C}$. In the present study, the probiotic dose was 
Table 1. Formulation and proximate composition of the experimental diets

\begin{tabular}{|c|c|c|c|c|}
\hline Ingredients (\%) & \multicolumn{4}{|c|}{ Diet } \\
\hline Commercial feed & \multicolumn{4}{|c|}{100} \\
\hline Tapioca & \multicolumn{4}{|c|}{3} \\
\hline Pro/pre/synbiotic & \multicolumn{4}{|c|}{$*$} \\
\hline \multirow{2}{*}{$\begin{array}{l}\text { Proximate analysis } \\
\text { (\% dry matter) }\end{array}$} & \multicolumn{4}{|c|}{ Treatments } \\
\hline & Control & Feed with $1 \%$ probiotic & Feed with $2 \%$ prebiotic & Feed with synbiotic \\
\hline Crude protein & 31.33 & 31.17 & 31.17 & 31.17 \\
\hline Crude fat & 5.04 & 5.07 & 5.15 & 5.12 \\
\hline Nitrogen-free extract & 34.65 & 34.86 & 35.49 & 34.94 \\
\hline Energy $(\mathrm{kcal} / \mathrm{kg} \text { feed })^{* *}$ & 237.12 & 237.29 & 239.50 & 237.92 \\
\hline Moisture & 10.98 & 10.91 & 9.86 & 9.77 \\
\hline
\end{tabular}

* Control, $1 \%$ Probiotic, $2 \%$ prebiotic, and synbiotic (1\% probiotic and 2\% prebiotic) (g/100 g feed)

** DE: digestible energy = carbohydrate: $2.5 \mathrm{kcal}$ DE; protein: $3.5 \mathrm{kcal} \mathrm{DE}$, fat: $8.1 \mathrm{kcal} \mathrm{DE}(\mathrm{NRC}, 1993)$.

according to Putra (2014), i.e $2 \%$ (g/100 g) sweet potato extract. Then, the composition of synbiotic in this study referred to the previous dose of Putra et al. (2015), i.e $1 \%$ Bacillus NP5 (g/100 g) and $2 \%$ sweet potato extract $(\mathrm{g} / 100 \mathrm{~g})$.

\section{Diets and experimental design}

The composition of the experimental diets is described in Table 1. The commercial feed used in this study contained identical nutrient content (protein, lipid, energy, moisture) for all treatments. The present study consisted of four treatments and three replications, including control, feed with probiotic $1 \%$, prebiotic $2 \%$ and, synbiotic (probiotic 1\% + prebiotic 2\%). The commercial feed was mashed into the meal, then $3 \%$ of tapioca added as a binder in each feed. Furthermore, sweet potato extracts of $2 \%$ were added to prebiotic and synbiotic feed before the pelleting process. Probiotic added to the feed by spraying using a syringe with adding egg yolk of 2\% (Putra et al., 2015). Feeding was done three times a day using at satiation feeding method. The tested fish (Clarias sp.) used in this study had an average weight of $10.03 \pm 0.05 \mathrm{~g}$ at a density of 200 fish per tank. The experimental fish were reared in a round tank with a diameter of $200 \mathrm{~cm}$ for 45 days. Replacement of water in the rearing aquarium as much as $50 \%$ of total volume (200 L) were conducted every 2 days to maintain water quality.

\section{Experimental parameters}

Samples (diets and fish) were analyzed for dry matter, protein, lipid, moisture, nitrogen-free extract (NFE), and ash using a standard method (AOAC, 1995). Samples of fish were dried to a constant weight at $105^{\circ} \mathrm{C}$ for $6 \mathrm{~h}$ to determine moisture. Protein was determined by measuring nitrogen using the Kjeldahl system method, lipid by ether extraction using Soxhlet, and ash by combustion at $550^{\circ} \mathrm{C}$ for $24 \mathrm{~h}$. All chemical analysis was performed in duplicate and averaged. The data obtained from the trial were analyzed for survival rate (SR) and specific growth rate (SGR), that were determined according to Huisman (1987). Feed conversion ratio (FCR), nutrient

$\mathrm{FCR}=\frac{\text { Feed consumption }}{\text { Weight gain }} \times 100$

$\begin{aligned} & \text { Nutrient } \\ & \text { retention }\end{aligned}=100 \times \frac{\text { Final body nutrient-initial body nutrient }}{\text { protein intake }(\mathrm{g})}$

PER $=\frac{\text { Wet weight gain }}{\text { Protein intake }} \times 100$

$\underset{(\% / \text { day })}{\mathrm{SGR}}=\frac{100(\text { Ln final weight }- \text { Ln initial weight })}{\text { days }} \times 100$

$\mathrm{SR}=\frac{\text { Total individuals at the final }}{\text { Total individuals at the initial }} \times 100$

(protein and fat) retention, and protein efficiency ratio (PER) (Takeuchi, 1988) using the following formula.

\section{Digestive enzymes activity}

The enzyme activities measured were the activity of protease and lipase according to the method by Bergmeyer and Grassi (1983). To measure digestive enzyme activity, intestine samples of catfish were homogenized in an icecold buffer. At the end of the experiment, five 
Table 2. Effects of dietary Bacillus NP5 and sweet potato extract on growth of dumbo catfish.

\begin{tabular}{lcccc}
\hline \multirow{2}{*}{ Parameter*** } & \multicolumn{3}{c}{ Treatments $(\mathrm{g} / 100 \mathrm{~g})^{*}$} \\
\cline { 2 - 5 } & Control & $1 \%$ probiotic & $2 \%$ prebiotic & Synbiotic $^{* *}$ \\
\hline IW (g) & $10.04 \pm 0.05$ & $10.07 \pm 0.04$ & $10.04 \pm 0.05$ & $10.05 \pm 0.05$ \\
FW (\%) & $97.40 \pm 1.28^{\mathrm{a}}$ & $115.04 \pm 1.05^{\mathrm{b}}$ & $114.67 \pm 2.08^{\mathrm{b}}$ & $139.90 \pm 0.17^{\mathrm{c}}$ \\
PR (\%) & $32.10 \pm 1.09^{\mathrm{a}}$ & $38.70 \pm 1.86^{\mathrm{b}}$ & $40.22 \pm 1.53^{\mathrm{b}}$ & $48.02 \pm 1.30^{\mathrm{c}}$ \\
FR (\%) & $53.51 \pm 2.12^{\mathrm{a}}$ & $62.41 \pm 1.34^{\mathrm{b}}$ & $62.37 \pm 0.57^{\mathrm{b}}$ & $62.63 \pm 1.47^{\mathrm{b}}$ \\
SGR (\%/day) & $4.87 \pm 0.02^{\mathrm{a}}$ & $5.25 \pm 0.03^{\mathrm{b}}$ & $5.26 \pm 0.04^{\mathrm{b}}$ & $5.67 \pm 0.03^{\mathrm{c}}$ \\
FCR & $1.50 \pm 0.02^{\mathrm{c}}$ & $1.31 \pm 0.01^{\mathrm{b}}$ & $1.30 \pm 0.02^{\mathrm{b}}$ & $1.09 \pm 0.01^{\mathrm{a}}$ \\
PER (\%) & $2.13 \pm 0.03^{\mathrm{a}}$ & $2.45 \pm 0.02^{\mathrm{b}}$ & $2.46 \pm 0.05^{\mathrm{b}}$ & $2.95 \pm 0.04^{\mathrm{c}}$ \\
SR (\%) & $92.33 \pm 0.29^{\mathrm{a}}$ & $92.50 \pm 0.50^{\mathrm{a}}$ & $92.50 \pm 0.50^{\mathrm{a}}$ & $92.33 \pm 0.58^{\mathrm{a}}$ \\
\hline
\end{tabular}

"The value in the same row followed by similar superscript letters are not significantly different $(\mathrm{P}>0.05)$.

** (1\% probiotic Bacillus NP5 $+2 \%$ prebiotic)

***Initial weight (IW), final weight (FW), protein retention (PR), fat retention (FR), specific growth rate (SGR), feed conversion ratio (FCR), protein efficiency ratio (PER), and survival rate (SR) of dumbo catfish.

catfish from each tank were taken. The entire alimentary tract was quickly removed and placed on ice. The intestines were washed thoroughly with chilled saline and then dried quickly on a piece of filter paper and weighed. Furthermore, they were homogenized into 10 volumes $(\mathrm{w} / \mathrm{v})$ of ice-cold distilled water at $1,000 \times g$ for $5 \mathrm{~min}$, respectively. Homogenates were centrifuged at $10,000 \times g$ for $30 \mathrm{~min}$ at $4^{\circ} \mathrm{C}$ to analyze protease and amylase activity and, 1,660 $\times g$ for $20 \mathrm{~min}$ at $4^{\circ} \mathrm{C}$ to analyze lipase activity.

\section{Statistical analysis}

All statistical analysis was carried out using the statistical package for the social sciences (SPSS 16.00) program for Windows. Data were expressed as the average of three replicates and was compared using ANOVA. Where significant differences were found, the means within each treatment and among treatments were compared using Duncan of multiple comparisons with a 95\% significant level.

\section{RESULTS AND DISCUSSION}

\section{Growth}

Growth performance of dumbo catfish fed experimental diet is shown in Table 2. The final weight of fish in synbiotic treatment was of $139.90 \pm 0.17 \mathrm{~g}$ and it was significantly higher $(\mathrm{P}<0.05)$ than the other treatments. The protein retention was highest in synbiotic $(48.02 \pm 1.30 \%)$ and the lowest was in control $(32.10 \pm 1.09 \%)$. Furthermore, there was no difference in protein retention between probiotic $(38.70 \pm 1.86)$ and prebiotic $(40.22 \pm 1.5 \%)$ treatment. Fat retention was significantly higher in synbiotic treatment $(62.63 \pm 1.47 \%)$ compared to the control (53.51 $\pm 2.12 \%$ ), but there was no difference between probiotic, prebiotic, and synbiotic treatment. The addition of synbiotic to diets also produced the best specific growth rate, with statistically values better than the other treatments $(\mathrm{P}<0.05)$. The value of specific growth rate was significantly highest $(\mathrm{P}<0.05)$ in synbiotic $(5.67 \pm 0.03 \% /$ day), followed by prebiotic (5.26 $\pm 0.04 \% /$ day $)$, probiotic $(5.25 \pm 0.03 \% /$ day $)$ and the lowest in the control $(4.87 \pm 0.02 \% /$ day $)$. The value of feed conversion ratio (FCR) in synbiotic $(1.09 \pm$ $0.01)$ was lower $(\mathrm{P}<0.05)$ than that of the other treatments. Protein efficiency ratio (PER) of fish in probiotic, prebiotic and synbiotic treatments showed significant higher $(\mathrm{P}<0.05)$ than the control one. The survival rate of feeding trial in controls, probiotic, prebiotic and synbiotic showed no significant different $(\mathrm{P}>0.05)$.

\section{Enzyme activity}

After cultured for 45 days, the average digestive enzyme activities in probiotic, prebiotic, and synbiotic treatment were significantly different from that of the control (Figure 1). The protease activity was significantly higher in synbiotic $(0.77 \pm 0.01 \mathrm{U} / \mathrm{min} / \mathrm{mL})$ compared with probiotic $(0.73 \pm 0.02 \mathrm{U} / \mathrm{min} / \mathrm{mL})$, prebiotic $(0.72 \pm 0.01 \mathrm{U} / \mathrm{min} / \mathrm{mL})$, and control $(0.56 \pm$ $0.01 \mathrm{U} / \mathrm{min} / \mathrm{mL}$ ) treatment, but there was no significant $(\mathrm{P}>0.05)$ difference between probiotic and prebiotic (Figure 1). Lipase activity was significantly $(\mathrm{P}<0.05)$ higher in synbiotic $(0.54$ $\pm 0.01 \mathrm{U} / \mathrm{min} / \mathrm{mL})$ and prebiotic $(0.56 \pm 0.02 \mathrm{U} /$ $\mathrm{min} / \mathrm{mL})$ compared with probiotic $(0.52 \pm 0.01$ $\mathrm{U} / \mathrm{min} / \mathrm{mL})$ and control $(0.46 \pm 0.01 \mathrm{U} / \mathrm{min} /$ $\mathrm{mL})$. Amylase enzyme showed higher activity $(\mathrm{P}<0.05)$ in probiotic, prebiotic, and synbiotic treatment compared with control. However, there 


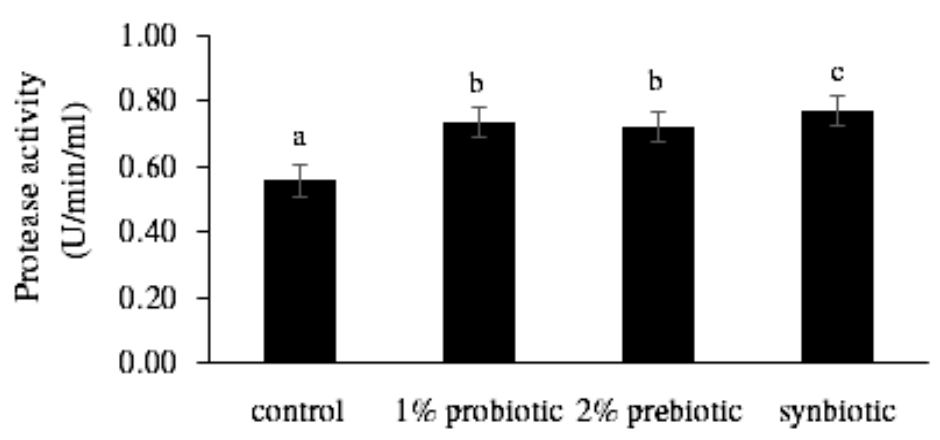

(i)

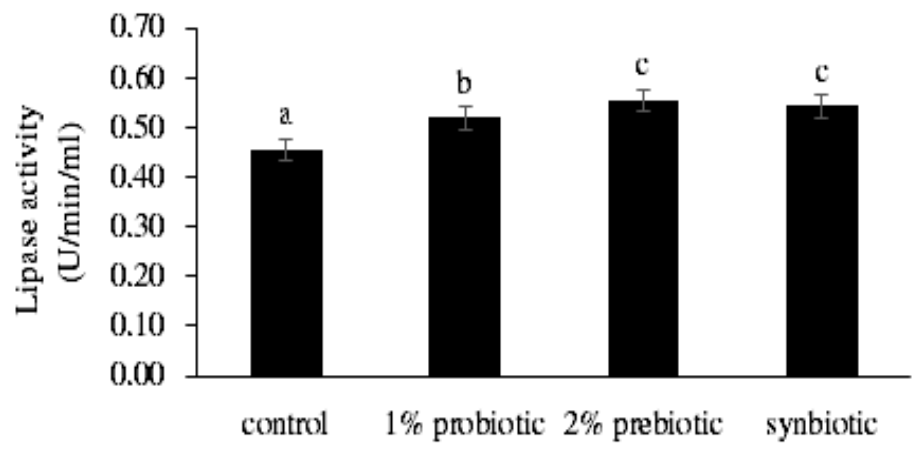

(ii)

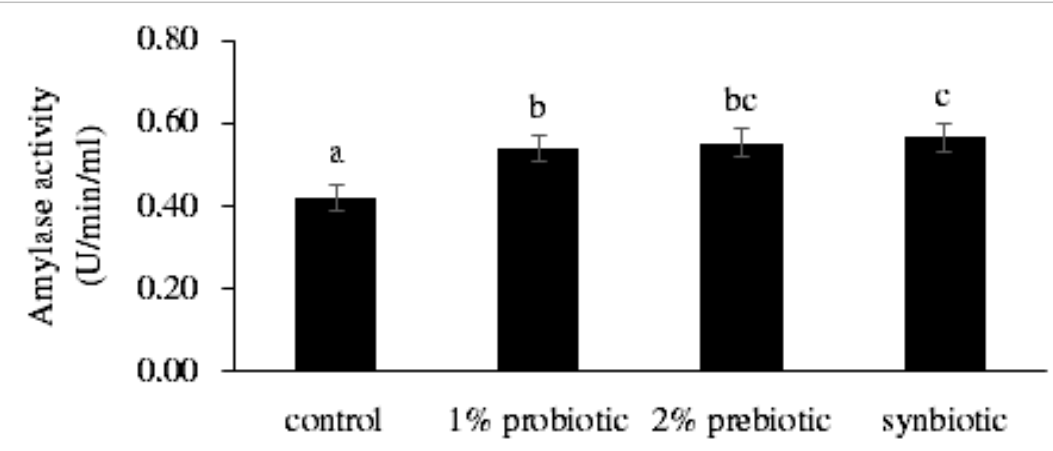

(iii)

was no difference $(\mathrm{P}>0.05)$ between probiotic and prebiotic treatment.

\section{Discussion}

Probiotic, prebiotic, and synbiotic have been proven to improve growth and physiological aspects in various aquaculture species. Probiotic, prebiotic, and synbiotic supplemented diets resulted in better growth performances than that of the control (Table 2). Similar results were observed by Daniels et al. (2010) in the European lobster (Homarus gammarus L.) larvae, Ai et al. (2011) in juvenile large yellow croaker, Putra et al. (2015) in tilapia, Nurhayati et al. (2015) in white shrimp, and Kumar et al. (2017) in Cirrhinus mrigala (Ham.) fingerling. In the present study, the combination of Bacillus NP5 and prebiotic of extracted sweet potatoes var. sukuh (Ipomoea batatas) has appeared to improve growth performance in terms of FW and SGR, and also for PR, FCR, PER, and protease activity in dumbo catfish.

Nutrients retention is the amount of nutrient which could be absorbed from the feed and stored in the fish body. In the present study, the supplementation of synbiotic showed higher protein retention as compared to the control and other treatments. Similarly, fat retention value was higher than the control. This result is supported by the study of Putra et al. (2015) who observed a positive effect of synbiotic on growth performance in tilapia. Marlida et al. (2015) noted that synbiotic application can improve growth, digestive enzyme activity and health status of 
humpback grouper. The addition of probiotic and prebiotic in feed intended to increase the population of microbiota in the digestive tract of host, so that the action mechanism of microbiota in producing enzymes for digestion will increase (Merrifield et al., 2010), and will improve the amount of nutrient which could be absorbed by fish. In this study, there was no difference in fat retention between prebiotic and synbiotic treatment, indicating that the amount of lipase enzyme activity in the digestive tract has no difference. This is indicated that prebiotic and synbiotic treatment have a similar effect to increase lipolytic bacteria on the digestive tract of catfish. This is shown by the activity of the lipase enzyme which was no significance between prebiotic and synbiotic treatments. One potential mechanism of probiotic and prebiotic is the colonization of beneficial bacteria (Buentello et al., 2010). The beneficial bacteria can produce digestive enzyme such as protease, lipase, and amylase which have to function is to digest macronutrients from feed into a form that can be absorbed by fish (Nimrat et al., 2013).

The increased activity of retention nutrient has a positive correlation to SGR, FCR, and PER. Synbiotic treatment showed the best value in SGR, FCR, and PER compared with other treatments. Kumar et al. (2017) also showed that the combined supplementation of Bacillus subtilis $(100 \mathrm{~g} / \mathrm{kg})$ and MOS $(4 \mathrm{~g} / \mathrm{kg})$ as synbiotic enhanced $\%$ weight gain, SGR, FCR, and PER of about 75.80, 0.94, 2.66 , and $1.06 \%$, respectively, compared to the control, in Cirrhinus mrigala (Ham.) fingerling. These findings were also similar to the previous study by Daniels et al. (2010) who showed that application of a commercial probiotic (Bacillus spp.) and mannan oligosaccharides (MOS) as synbiotic, could increase SGR of European lobster (Homarus gammarus L.) larvae. The increased activity of the digestive enzymes could help the host in degrading nutrients, improving digestibility and increasing feed efficiency (Cerezuele et al., 2011). The study of Nurhayati et al. (2015) in white shrimp showed that after 30 days, the combination of $1 \%$ probiotic and $2 \%$ prebiotic supplemented with the feed to the shrimp culture improved the daily growth rate and decreased FCR.

The combined application of probiotic and prebiotic is known as synbiotic, which work by improving the survival and colonization of live microbial dietary supplements (probiotic) in the gastrointestinal tract which can promote health and thus improve the welfare of the host (Daniels et al., 2010). In this study, there was no difference in survival rate among treatments, indicating that the addition of probiotic, prebiotic and synbiotic to feed did not affect to fish health. The similar result reported by Akrami et al. (2015) who found the addition of synbiotic showed no difference in the survival rate of beluga (Huso huso) compared to the control.

The combined use of probiotic and prebiotic is a new concept in aquaculture and the present study has not only highlighted significantly improved catfish growth performance in comparison to unsupplemented diets, but also demonstrated even greater success in digestive enzyme activity (protease, lipase, and amylase activity). In the present study, the addition of probiotic, prebiotic, and synbiotic to feed resulted in better digestive enzyme activity than that of the control (Figure 1). A similar result has been reported by Putra et al. (2015) in tilapia and Munir et al. (2016) in snakehead Channa striata fingerlings. The supplementation of synbiotic showed higher protease activity as compared to the control and the other treatments. A similar result also occurred in the study on the addition of synbiotic to feed which could improve protease activity in Cirrhinus mrigala (Ham.) fingerling (Kumar et al., 2017). The higher level of enzyme activity obtained with diets containing probiotic improved the digestion of protein, starch, and fat which might, in turn, explain the better growth performance observed with the synbiotic supplemented diets.

Probiotic and prebiotic beneficially affect the host by improving the survival and implantation of live microbial dietary supplements in the gastrointestinal tract (Dawood \& Koshio, 2016). Bacillus NP5 is probiotic bacteria isolated from the digestive tracts of tilapia which has the activity of amylase (Putra \& Widanarni, 2015), protease, and lipase (Putra et al., 2015). In this study there was no difference in growth performance parameter (FW, PR, FR, SGR, FCR, and PER) and digestive enzyme activity (protease, lipase, and amylase activity) between probiotic and prebiotic treatment, indicating that the addition of probiotic and prebiotic to fed did a similar effect to increase the population of microbiota in the digestive tract of catfish. The population of these microbiota depends on the survival capability, colonization, and nutrient competition, and environmental changewhich caused bacteria living in the digestive system be washed out 
(Goubeyre et al., 2011). Similar effects had been reported by Daniels et al. (2010) that no difference in FW, live weight gain, SGR, and FCR between probiotic and prebiotic treatment in European lobster Homarus gammarus (Linn.) larvae.

\section{CONCLUSION}

In conclusion, the addition of probiotic, prebiotic, and synbiotic to diets showed significant result on final weight, specific growth rate, feed conversion ratio, protein retention, protein efficiency ratio, and enzyme activities compared to the control $(\mathrm{P}<0.05)$. These results revealed that the combination of Bacillus NP5 1\% and prebiotic $2 \%$ (extracted from sweet potatoes Ipomoea batatas var. sukuh) as synbiotic in feed showed the best result compared to other treatments and it can be applicated for dumbo catfish culture.

\section{ACKNOWLEDGMENTS}

This research was funded by DIPA UNTIRTA with scheme of Decentralized Research Program (Program Penelitian Desentralisasi: Hibah Bersaing), contract number: 268/UN43.9/ PL/K/2016. The authors also thank Tri Farm for the guidance in fish culture.

\section{REFERENCES}

Akhter N, Wu B, Menon AM, Mohsin M. 2015. Probiotics and prebiotics associated with aquaculture: a review. Fish and Shellfish Immunology 45: 733-741.

Agung AL, Widananrni, Yuhana M. 2015. Application of micro-encapsulated probiotic Bacillus NP5 and prebiotic mannan oligosaccharide (MOS) to prevent streptococcosis on tilapia Oreochromis niloticus. Research Journal of Microbiology 10: 571-581.

Ai Q, Xu H, Mai K, Xu W, Wang J, Zhang W. 2011. Effects of dietary supplementation of Bacillus subtilis and fructooligosaccharide on growth performance, survival, non-specific immune response and disease resistance of juvenile large yellow croaker, Larimichthys crocea. Aquaculture 317: 155-161.

Akrami R, Nasri-Tajan R, Jahedi A, Jahedi M, Mansour MR, \& Jafarpour SA. 2015. Effects of dietary synbiotic on growth, survival, lactobacillus bacterial count, blood indices and immunity of beluga Huso huso (Linnaeus, 1754) juvenile. Aquaculture Nutrition 21: 952-959.

Anuta JD, Buentello A, Patnaik S, Hume ME, Mustafa A, Gatlin III DM, Lawrence AL. 2014. Effects of dietary supplementation of a commercial prebiotic Previda ${ }^{\circledR}$ on survival, growth, immune responses and gut microbiota of Pacific white shrimp, Litopenaeus vannamei. Aquaculture Nutritions 22: 410-418.

AOAC (Association of Official Agriculture Chemists). 1995. Official Methods of Analysis. $16^{\text {th }}$ ed Volume II: Maryland.

Arig N, Suzer C, Gökvardar A, Basaran F, Coban D, Yildirim S, Kamaci HO, Firat K, Saka S. 2013. Effects of probiotic Bacillus sp. supplementation during larval development of gilthead sea bream Sparus aurata (Linn.). Turkish Journal of Fisheries and Aquatic Sciences 13: 407-414.

Bergmeyer HU, Grassi. 1983. Methods of Enzymatic Analysis. Volume 2, Weinheim: Verlag Chemie.

Buentello JA, Neil WH, Gatlin DM III. 2010. Effects of dietary probiotics on the growth, feed efficiency and non-specific immunity of juvenile red drum Sciaenops ocellatus fed soybean-based diets. Aquaculture Research 41: 411-418.

Cerezuela R, Meseguer J, Esteban M. 2011. Current knowledge in synbiotic use for fish aquaculture: a review. Journal of Aquaculture Research \& Development 1: 1-7.

Daniels CL, Merrifield DL, Boothroyd DP, Davies SJ, Factor JR, Arnold KE. 2010. Effect of dietary Bacillus spp. and mannan oligosaccharides (MOS) on European lobster Homarus gammarus (Linn. larvae growth performance, gut morphology, and gut microbiota. Aquaculture 304: 49-57.

Dawood MAO, Koshio S, Ishikawa M, Yokoyama S. 2015. Effects of heat-killed Lactobacillus plantarum (LP20) supplemental diets on growth performance, stress resistance and immune response of red sea bream Pagrus major. Aquaculture 442: 29-36.

Dawood MAO \& Koshio S. 2016. Recent advances in the role of probiotics and prebiotics in carp aquaculture: a review. Aquaculture 454: 243251.

Dawood MAO, Koshio S, Ishikawa M, ElSabagh M, Yokoyama S, Wang WL, Yukun 
Z, Olivier A. 2017. Physiological response, blood chemistry profile and mucus secretion of red sea bream Pagrus major fed diets supplemented with Lactobacillus rhamnosus under low salinity stress. Fish Physiology and Biochemistry 43: 179-192.

De BC, Meena DK, Behera BK, Das P, Das Mohapatra PK, Sharma AP. 2014. Probiotics in fish and shellfish culture: immunomodulatory and ecophysiological responses. Fish Physiology and Biochemistry 40: 921-971.

Ekasari J, Crab R, Verstraete W. 2010. Primary nutritional content of bio-flocs cultures with different organic carbon sources and salinity. Hayati Journal of Biosciences 17: 125-130.

Direktorat Jendral Perikanan Budidaya. 2016. Laporan Kinerja Direktorat Jendral Perikanan Budidaya Tahun 2016. Kementrian Kelautan dan Perikanan, Indonesia. 84p.

Geng X, Dong XH, Tan BP, Yang QH. Chi SY, Liu HY, Liu XQ. 2012. Effects of dietary probiotic on the growth performance, nonspecific immunity and disease resistance of cobia Rachycentron canadum. Aquaculture Nutrition 18: 46-55.

Geraylou Z, C Souffreau, E Rurangwa, L De Meester, CM Courtin, JA Delcour, J Buyse, and F Ollevier. 2013. Effects of dietary arabinoxylan-oligosaccharides (AXOS) and endogenous probiotics on the growth performance, non-specific immunity and gut microbiota of juvenile Siberian sturgeon Acipenser baerii. Fish and Shellfish Immunology 35: 766-775.

Giri SS, Sukumaran V, Oviya M. 2013. Potential probiotic Lactobacillus plantarum VSG3 improves the growth, immunity, and disease resistance of tropical freshwater fish, Labeo rohita. Fish \& Shellfish Immunology 34: 660-666.

Goubeyre P, Denery S, Bodnier M. 2011. Probiotics, prebiotics, and synbiotics: impact on the gut immune system and allergic reactions. Journal of Leukocyte Biology 89: 685-595.

Grisdale HB, Helland SJ, Galtlin. 2008. The effects of dietary supplementation with mannan oligosaccharide, fructooligosaccharide or galactooligosaccharide on the growth and feed utilization of Atlantic salmon Salmo salar. Aquaculture 283: 163-167.

Hauville MR, Zambonie-Infante JL, Bell JG, Migaud H, Main KL. 2016. Effects of a mix of Bacillus sp. as a potential probiotic for Florida pompano, common snook and re drum larvae performances and digestive enzyme activities. Aquaculture Nutrition 22: 51-60.

Huisman EA. 1987. Principles of fish production. Department of Fish Culture and Fisheries, Wageningen Agriculture University, Wageningen: Netherland.

Ibrar M,Zuberi A, Amir I, Imran M, Noor,Z. 2017. Effect of probiotic Geotrichum candidum on early rearing of Labeo rohita (Hamilton, 1822). Turkish Journal of Fisheries and Aquatic Sciences 17: 1263-1270.

Imanpoor M, Rohi Z. 2015. Influence of primalac probiotic on growth performance, blood biochemical parameters, survival and stress resistance in the Caspian roach Rutilus rutilus fry. Turkish Journal of Fisheries and Aquatic Sciences 15: 917-922.

Kumar P, Jain KK, Sardar P, Jayant M, Tok CN. 2017. Effect of dietary on growth performance, body composition, digestive enzyme activity, and gut microbiota in Cirrhinus mrigala (Ham.) fingerling. Aquaculture Nutrition 00: 1-9.

Lin S, Mao S, Guan Y, Luo L, Luo L, Pan Y. 2012. Effects of dietary chitosan oligosaccharides and Bacillus coagulans on the growth, innate immunity and resistance of koi Cyprinus carpio koi. Aquaculture 342: 36-41.

Marlida R, Suprayudi MA, Widanarni, Harris E. 2014. growth, digestive enzyme activity and health status of humpback grouper Cromileptes altivelis fed with synbiotic. Pakistan Journal of Nutrition 13: 319-326.

Merrifiled DL, Dimitroglou A, Foey A, Davies SJ, Baker RTM, Bogwald J, Castex M, Ringo E. 2010. The current status and future focus of probiotic and prebiotic applications for salmonids. Aquaculture 302: 1-18.

Moongngarm AN, Trachoo N, Sirigungwan N. 2011. Low molecular weight carbohydrates, prebiotic content and prebiotic activity of selected food plants in Thailand. Journal of Food Science and Technology 3: 269-274.

Muchtadi D. 1989. Evaluation of food nutritive values [In Bahasa Indonesia]. Department of Education and Culture. Directorate of Higher Education-InterUniversity Center, Indonesia.

Munir MB, Hashim R, Chai YH, Marsh TL, Nor SAM. 2016. Dietary prebiotics and probiotics influence growth performance, nutrient digestibility and the expression of immune 
regulatory genes in snakehead Channa striata fingerlings. Aquaculture 460: 59-68.

Nayak SK. 2010. Probiotics and immunity: a fish perspective. Fish Shellfish Immunology 29: 2-14.

Nimrat S, Tanutpongpalin P, Sritunyalucksana K, Boonthai T, Vuthiphandchai. 2013. Enhancement of growth performance, digestive enzyme activities and disease resistance in black tiger shrimp Penaeus monodon postlarvae by potential probiotics. Aquaculture International 21: 655-666.

NRC (National Research Council). 1993. Nutrient Requirement of Fish. National Academic Press. Washington D. C. 273pp.

Nurhayati D, Widanarni, Yuhana M. 2015. Dietary synbiotic on the growth performance and immune responses to co-infection with infectious myonecrosis virus and Vibrio harveyi in Litopenaeus vannamei. Journal of Fisheries and Aquatic Science 10: 13-23.

Putra AN. 2014. Sweet potato varieties sukuh potential as a prebiotic in tilapia feed Oreochromis niloticus. Sudaryono, A. \& Mufid, A. (Eds.). Proceeding of International Conference of Aquaculture Indonesia (pp. 254-258). Semarang, Indonesia, Masyarakat Akuakultur Indonesia. 311 pp.

Putra AN, Widanarni. 2015. Screening of amylolytic bacteria as candidates of probiotics in tilapia Oreochromis sp.. Research Journal of Microbiology 10: 1-13.

Putra AN, Widanarni, Utomo NBP. 2015. Growth performance of tilapia Oreochromis niloticus fed with probiotic, prebiotic and synbiotic in diet. Pakistan Journal of Nutrition 14: 263-268.

Ring $\varnothing$ E, Olsen RE, Gifstad TØ, Dalmo RA, Amlund H, Hemre GI, Bakke AM. 2010. Prebiotics in aquaculture: a review. Aquaculture Nutrition 16: 117-136.

Ring $\varnothing$ E, Dimitroglou A. Hoseinifar SH, Davies SJ. 2014. Prebiotics in finfish: an update. In: Aquaculture Nutrition: Gut Health, Probiotics and Prebiotics (Ring $\varnothing$, E. \& Merrifield, D. eds), in press. Wiley-Blackwell, Oxford, UK.

Selim KM \& Reda RM. 2015. Beta-glucans and mannan oligosaccharides enhance growth and immunity in Nile tilapia. North American Journal of Aquaculture 77: 22-30.

Song SK, Beck BR, Kim D, Park J, Kim J, Kim HD, Ringg ø 2014. Prebiotics as immunostimulants in aquaculture: a review. Fish \& Shellfish Immunology 40: 40-48.

Takeuchi. 1988. Laboratory Work-Chemical Evaluation of Dietary Nutrients. P.179233, In Watanabe (Ed) Fish Nutrition and Mariculture. Kanagawa International Fisheries Training. Japan International Cooperation Agency (JICA), Japan.

Tamamdusturi R, Widanarn, Yuhana M. 2016. Administration of microencapsulated probiotic Bacillus sp. NP5 and prebiotic mannan oligosaccharide for prevention of Aeromonas hydrophila infection on Pangasianodon hypopthalmus. Journal of Fisheries and Aquatic Science 11: 67-76.

Utami DAS, Widanarni, Suprayudi MA. 2015. Quality of dried Bacillus NP5 and its effect on growth performance of tilapia Oreochromis niloticus. Pakistan Journal of Biological Sciences 18: 88-93.

Wang J, Zhang D, Sun Y, Wang S, Li P, Gatlin III DM, Zhang L. 2014. Effect of a dairyyeast prebiotic (Grobiotic -A) on growth performance, body composition, antioxidant capacity and immune functions of juvenile starry flounder Platichthys stellatus. Aquaculture research: 1-11.

Widanarni, Ekasari J, Maryam S. 2012. Evaluation of biofloc technology application on water quality and production performance of red tilapia Oreochromis sp. cultured at different stocking densities. Hayati Journal of Biosciences 19: 73-80.

Widanarni, Yuhana M, Muhamad A. 2014. Bacillus NP5 improves growth performance and resistance against infectious myonecrosis virus in white shrimp Litopenaeus vannamei. Ilmu Kelautan 19: 211-218.

Widanarni, Sukenda, Damayanti. 2016. Effets of the synbiotic on the growth performance, immune response and resistance to infectious myonecrosis virus in white shrimp Litopenaeus vannamei. Journal of King Abdulaziz University 26: 9-18.

Zhang CN, Li XF, Xu WN, Jiang GZ, Lu KL, Wang LN, Liu WB. 2013. Combined effects of dietary fructooligosaccharide and Bacillus licheniformis on innate immunity, antioxidant capability and disease resistance of triangular bream Megalobrama terminalis. Fish \& Shellfish Immunology 35: 1380-1386. 